\title{
Kajian Mutu Kimia Bubuk Kopi Espresso Aceh Berdasarkan Rasio Pencampuran dan Teknik Penyangraian Varietas Kopi Arabika dan Robusta
}

\author{
Dian Hasni ${ }^{1}$, Murna Muzaifa ${ }^{1}$, Dedy Rahmad ${ }^{2}$, Maulana Insan ${ }^{1}$ \\ ${ }^{1}$ Program Studi Teknologi Hasil Pertanian, Fakultas Pertanian Universitas Syiah Kuala, Banda Aceh \\ ${ }^{2}$ Progran Studi Teknik Kimia, Politeknik ATI Padang, Bungo Pasang-Padang
}

\section{ARTICLE INFORMATION}

Received: November 19, 2021

Revised: December 13, 2021

Available online: December 29, 2021

\section{KEYWORDS}

Arabica, Coffee Blend, Espresso, Robusta, Torrefacto

\section{CORRESPONDENCE}

Name: Dedy Rahmad

E-mail: rahmad.dedy@gmail.com

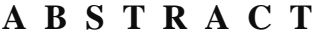

Generally there are two coffee varietes cultivated in Indonesia, known as Arabica and Robusta coffee. Arabica distinctively known for its distinctive quality but limited quantity compared to robusta which is commonly use for commercial coffee production due to its robust productivity. Nowadays, global market demand encourages a huge variety of coffee product, based on coffee such as espresso. The quality of espresso is influence by many factors such as roasting technique and ratio blending of coffee ground. This study aims to determine the influence of blending ratio and roasting techniqus to the chemical compounds of coffee ground and its espresso brewed. This research used Factorial Random Design, consists of 2 factors. First factor is ratio of blending Arabica and Robusta with three levels ratio; $\mathrm{B} 1=70: 30 ; \mathrm{B} 2=80: 20$; and $\mathrm{B} 3=90: 10$ ). The second factor is roasting technique, consisting of 2 levels of conventional roasting(P1) and torrefacto (P2). Each treatment was repeated 3 replications to obtain 18 units of experiment. Measured parameters are $\mathrm{pH}$ of brewed espresso and moisture (\%), ash $(\%)$, protein (\%), lipid (\%) and caffeine (\%) contents of coffee ground. The results showed that the blending ratio was highly significant $(P \leq 0,01)$ to the moisture and protein contents of coffee grounds and $\mathrm{pH}$ of resulted espresso. The best treatment was obtained from combination of B1P1 treatment (combination blending ratio (70\%:30\%) and conventional roasting) with $2.00 \%$ moisture content, $4.83 \%$ ash, $13.04 \%$ protein, $10.41 \%$ fat, $81.17 \%$ carbohydrate and caffeine $1.49 \%$
\end{abstract}

\section{PENDAHULUAN}

Kopi (Coffea sp) merupakah salah satu dari lima komoditas perdagangan dunia selain teh dan cokelat (Nestle, 2004). Secara umum ada dua jenis kopi yang dibudidayakan di dunia termasuk Indonesia yaitu kopi Arabika dan kopi Robusta. Menurut data International Coffee Organization (ICO), Tahun 2021 Indonesia memproduksi kopi 12,10 juta bgas $(60 \mathrm{~kg} /$ bags $)$, meningkat sebanyak $5,80 \%$ dari tahun sebelumnya [1]. Indonesia merupakan negara produsen kopi dengan jumlah ekspor terbesar setelah Brazil, Kolombia dan Vietnam, mencapai 6,90 juta bags (60 kg/bags) [2] dengan data konsumsi mencapai 5,00 juta bags (60 $\mathrm{kg} /$ bags) dan dilaporkan meningkat sebesar $1.7 \%$ dari tahun sebelumnya [3]. Data ini menunjukkan bahwa kopi masih memiliki peran penting dalam pengembangan ekonomi baik di lokal maupun global, sebagai produk ekspor ataupun produk konsumsi masyarakat lokal.

Dataran Tinggi Gayo merupakan produsen kopi arabika terbesar di Indonesia. Selain itu Provinsi Aceh juga memproduksi kopi robusta. Peningkatan tren konsumsi kopi merupakan peluang pengembangan produk kopi [4]. Diversifikasi olahan kopi perlu dilakukan untuk menambah nilai produk baik secara ekonomi maupun mutu produk itu sendiri. Pada produk kopi dan turunannya, variasi penyajian kopi merupakan salah satu cara diversifikasi olahan dari kopi [5].

Variasi cara penyajian kopi saat ini semakin berkembang. Pesatnya permintaan pasar mendorong beragamnya penyajian kopi, salah satunya adalah kopi 
espresso yang banyak digemari oleh konsumen. Espresso juga merupakan bahan baku utama untuk menyajikan minuman berbasis kopi lainnya seperti cappucino, lattemachiato dan sebagainya. Kopi espresso disebut jenis kopi machine brewing, dimana kopi diseduh secara cepat kurang lebih 30 detik, dengan menggunakan mesin espresso [6]. Tahapan pembuatan espresso dimulai dari pemanasan awal mesin, pengisian keranjang poratfiler espresso dengan menggunakan bubuk kopi, tamping kopi, dan terakhir pemasangan pegangan portafilter [7].

Saat ini mutu kopi bukan hanya dinilai dari mutu kopi beras, tetapi juga dari citarasa seduhan kopi yang dihasilkan [8]. Citarasa kopi merupakan manifestasi dari komponen kimia yang dikandung oleh kopi beras yang terbentuk dalam penyangraian yang ditransformasi menjadi citarasa kopi yang spesifik [9]. Mutu dan citarasa secangkir kopi espresso dipengaruhi oleh banyak faktor yang sangat kompleks, dimulai dari budidaya, panen, pasca panen, pengolahan sekunder seperti penyangraian hingga penyeduhan [10].

Penyangraian merupakan operasi kesatuan yang penting dalam mengembangkan sifat organoleptik seperti rasa, aroma, dan warna yang mendasari suatu kualitas secangkir kopi [11]. Penyangraian secara umum atau disini dikenal dengan penyangraian konvensional dilakukan dengan pemberian panas kepada biji kopi beras sehingga terjadi perubahan volume, penampakan baik warna, tekstur dan flavour kopi tersebut [12]. Namun beberapa global roastery juga menggunakan teknik penyangraian torrefacto. Penyangraian torrefacto adalah penyangraian dengan penambahan gula sedangkan penyangraian konvensional adalah penyangraian tanpa penambahan gula [13].

Faktor lain yang mempengaruhi mutu kopi adalah proses blending yaitu pencampuran dua jenis kopi (Arabika dan Robusta) yang dapat meningkatkan nilai citarasa seduhan kopi yang dihasilkan. Dalam pembuatan kopi espresso, ketepatan pencampuran ini penting untuk menghasilkan citarasa yang diinginkan konsumen [14]. Busono [7] melaporkan bahwa salah satu formulasi kopi espresso yang sering digunakan adalah 90\% kopi Arabika dan $10 \%$ Robusta. Berdasarkan uraian tersebut, perlu dilakukan penelitian untuk mengetahui pengaruh teknik penyangraian dan rasio blending antara bubuk kopi Arabika dan Robusta terhadap komposisi kimia bubuk kopi espresso Aceh.

\section{METODOLOGI}

Penelitian ini dilakukan di Laboratorium Pengembangan Produk dan Pilot Plant, Laboratorium Analisis Pangan dan Hasil Pertanian Jurusan Teknologi Hasil Pertanian,
Fakultas Pertanian, Universitas Syiah Kuala Banda Aceh.

\section{Bahan dan Alat}

Varietas kopi yang digunakan pada penelitian ini diperoleh dari Aceh Tengah. Kopi arabika menggunakan kultivar Gayo 1 dari area tanam 1300 mdpl, dan kopi robusta kultivar multivarietas dari area tanam 1000 mdpl. Sedangkan bahan kimia yang di gunakan untuk analisa produk adalah $\mathrm{NaOH}, \mathrm{K}_{2} \mathrm{SO}_{4}, \mathrm{H}_{2} \mathrm{SO}_{4}, \mathrm{HCl}$, asam borat, kloroform, indikator methylen blue, methylen red, dan alkohol.

Alat yang digunakan pada penelitian ini mesin penyangrai kopi, grinder, mesin esppresso. Seluruh mesin untuk pengolahan kopi menggunakan merek Didacta Italia TA143D. Kemudian peralatan untuk keperluan analisa adalah Fujitsu timbangan analitik kapasitas $1 \mathrm{~kg}$, unit distilasi kjedahl, desikator, sokhlet, Shimadzu spectrophotometer UV-VIS dan peralatan gelas lainnya.

\section{Rancangan Penelitian}

Penelitian ini menggunakan Rancangan Acak Lengkap (RAL) faktorial yang terdiri atas 2 faktor. Faktor pertama yaitu rasio blending bubuk kopi Arabika dan Robusta yang terdiri dari 3 (tiga) taraf dengan perbandingan 70:30 (\%) (B1), 80:20 (\%) (B2), 90:10 (\%) (B3). Faktor kedua yaitu teknik penyangraian yang terdiri dari 2 taraf yaitu penyangraian konvensional (P1) dan torrefacto $(\mathrm{P} 2)$. Kombinasi perlakuan dalam penelitian ini adalah $3 \times 2=$ 6 (enam) kombinasi perlakuan, dan dilakukan ulangan sebanyak 3 kali. Sehingga diperoleh 18 satuan percobaan.

\section{Prosedur Penelitian}

Penyangraian (Modifikasi Wei dan Tanukora 2015)

Proses penyangraian mesin roaster Didacta Italia tipe TA143D. Penyangraian dimulai dengan pemanasan awal roaster pada suhu $190{ }^{\circ} \mathrm{C}$. Pada saat suhu roaster mencapai $125^{\circ} \mathrm{C}$ masing-masing kopi beras (Arabika dan Robusta) yang telah disortasi dan ditimbang sebanyak 3 $\mathrm{kg}$ selama 20 menit. Untuk penyangraian torrefacto, gula ditambahkan sebanyak $11 \%$ (berdasarkan berat bahan setelah disangrai) diakhir penyangraian selama \pm 10 menit dengan cara pemanasan manual. Kemudian biji kopi yang telah disangrai didinginkan pada suhu ruang. Selanjutnya dilakukan pengecilan ukuran biji kopi menggunakan grinder Didacta Italia tipe TA417D dengan ukuran 60 mesh sehingga dihasilkan bubuk kopi yang siap untuk dicampurkan.

\section{Proses Pencampuran Bubuk Kopi}

Proses blending dilakukan sebelum penyeduhan. Pencampuran dilakukan dengan pengadukan berulang 
secara manual dengan mencampurkan bubuk kopi Arabika dan Robusta sesuai perlakuan dalam persen 90:10, 80:20, 70:30 dan bubuk kopi siap dianalisis [15].

\section{Analisa Produk}

Analisa dilakukan pada bubuk kopi campuran dan seduhan espresso yang dihasilkan. Analisa kimia meliputi pengukuran kadar air, protein, lemak, abu dan kafein. Analisis dilakukan dengan merujuk pada prosedur AOAC [16].

\section{Analisis Data}

Data yang diperoleh dari analisa bubuk kopi dan seduhan espresso diolah secara ANOVA (Analysis of Variance) untuk menguji pengaruh dari setiap faktor dan interaksi antar faktor terhadap parameter produk. Apabila perlakuan terdapat pengaruh yang nyata maka harus dilakukan uji lanjut yaitu dengan menggunakan uji lanjut Beda Nyata Terkecil (BNT) taraf 0.05.

\section{HASIL DAN PEMBAHASAN}

\section{Komposisi Kimia Bahan Baku}

Komposisi kimia bahan baku mengacu kepada komponen kimia bubuk kopi sangrai yang dipublikasikan oleh Rahmad [17]. Data yang dijadikan acuan bahan baku adalah data komponen kimia bubuk kopi arabika dan robusta yang berasal dari eksperimen laboratorium, baik yang disangrai secara konvensional ataupun torrefacto. Data komponen kimia bahan baku dapat dilihat pada Tabel 1.

Kandungan air pada bubuk kopi yang disangrai dengan penambajan gula cenderung lebih rendah dikarenakan proses penyangraian yang lebih lama dibandingkan konvensional. Selain itu pada penelitian ini penyangraian dilakukan dengan kapasitas $3 \mathrm{~kg}$. Jumlah ini lebih rendah dibandingkan penyangraian pada kopi komersil yang mencapai $10 \mathrm{~kg}$ dalam setiap penyangraian [17].

\section{Kadar Air Bubuk Kopi Campuran}

Data hasil analisis kadar air pada bubuk kopi berkisar antara $1.07 \%$ hingga $2.47 \%$ dengan rata-rata $1.86 \%$. Hasil sidik ragam menunjukkan bahwa rasio blending Arabika: Robusta berpengaruh sangat nyata $(\mathrm{P} \leq 0.01)$ terhadap kadar air bubuk kopi yang dihasilkan.
Sedangkan teknik penyangraian serta interaksi kedua perlakuan berpengaruh tidak nyata $(\mathrm{P}>0.05)$ terhadap kadar air bubuk kopi espresso yang dihasilkan.

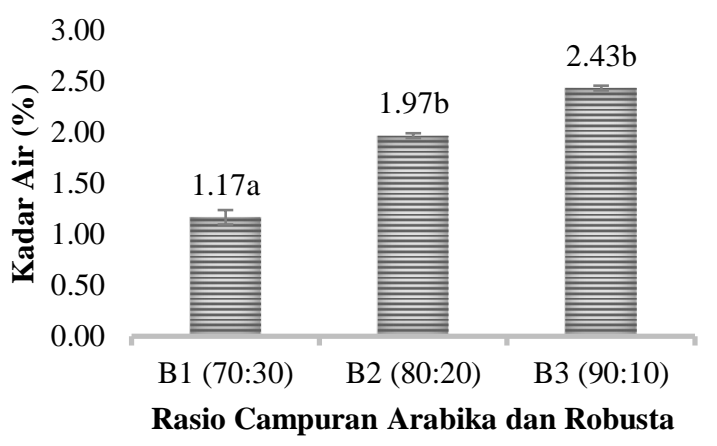

Gambar 1. Pengaruh rasio blending Arabika dan Robusta terhadap kadar air bubuk kopi espresso (nilai yang diikuti oleh huruf yang sama menunjukkan perbedaan yang tidak nyata), $\mathrm{KK}=3.47 \%$ dan $\mathrm{BNT}_{0,05} 0,49$

Gambar 1 menunjukkan bahwa kadar air bubuk kopi campuran dengan rasio Arabika: Robusta 70:30 (B1) berbeda nyata dengan kadar air bubuk kopi dari formulasi 80:20 (B2) dan 90:10 (B3). Untuk taraf B2 dan B3, keduanya berbeda tidak nyata satu sama lain. B1 memiliki kadar air yang lebih rendah dibandingkan dua taraf lainnya (1,17\%). Dari Gambar 1 dapat dilihat bahwa kadar air bubuk kopi espresso yang dihasilkan cenderung meningkat seiring dengan semakin besarnya persentase arabika pada formulasi bubuk kopi (B2 dan B3) dan sebaliknya jika persentase robusta lebih besar pada formulasi bubuk kopi (B1).

Hal ini diduga karena pada rasio blending (B1) penambahan robusta lebih banyak (30\%) di bandingkan jumlah Robusta pada perlakuan B2 dan B3. Sehingga kadar air bubuk kopi B2 dan B3 lebih tinggi dibandingkan B1. Hal ini sesuai dengan pengujian bahan awal, dimana kadar air bubuk kopi Arabika berkisar antra 3.20 - 4,00\% (Tabel 1). Nilai ini lebih tinggi dibandingkan kadar air bubuk kopi Robusta 1,60\%. Selanjutnya selain penyangraian, kadar air bubuk kopi juga dipengaruhi oleh proses pengolahan kopi beras. Mulato [5] menyatakan bahwa umumnya pengolahan Robusta dilakukan dengan cara kering sedangkan Arabika diolah secara basah. Dimana pengolahan cara kering dilaporkan menghasilkan kpi beras dengan kadar air yang lebih rendah dibandingkan cara basah.

Tabel 1. Komposisi Kimia Bahan Baku

\begin{tabular}{clcccc}
\hline \multirow{2}{*}{ No } & \multirow{2}{*}{ Komponen Kimia } & \multicolumn{2}{c}{ Arabika } & \multicolumn{2}{c}{ Robusta } \\
\cline { 3 - 5 } & & Konvensional & Torrefacto & Konvensional & Torrefacto \\
\hline 1. & Kadar Air & 4,00 & 3,20 & 1,60 & 1,60 \\
2. & Kadar Protein & 8,04 & 8,04 & 16,79 & 18,67 \\
3. & Kadar Lemak & 7,35 & 7,36 & 5,15 & 5,54 \\
4. & Kadar Abu & 4,00 & 4,50 & 5,00 & 5,00 \\
5. & Kadar Karbohidrat (by difference) & 76,60 & 76,60 & 71,96 & 69,19 \\
\hline
\end{tabular}

28 Hasni et al. 


\section{Kadar Protein}

Protein adalah senyawa asam amino mengandung unsur $\mathrm{C}$ dan N. Nitrogen (N) merupakan unsur yang tidak dimiliki karbohidrat dan lemak [18]. Kadar protein pada kopi dilaporkan berperan erat pada pembentukan rasa pahit $[8,19]$. Data hasil analisis kadar protein bubuk kopi campuran Arabika dan Robusta berkisar antara 8,67\% hingga $16,79 \%$ dengan rata-rata $11,82 \%$. Hasil sidik ragam menunjukkan faktor rasio blending Arabika : Robusta dan teknik penyangraian berpengaruh sangat nyata $(\mathrm{P} \leq 0.05)$ terhadap kadar protein bubuk kopi yang dihasilkan. Sedangkan interaksi kedua perlakuan menunjukkan pengaruh tidak nyata $(\mathrm{P}>0.05)$ terhadap kadar protein bubuk kopi.

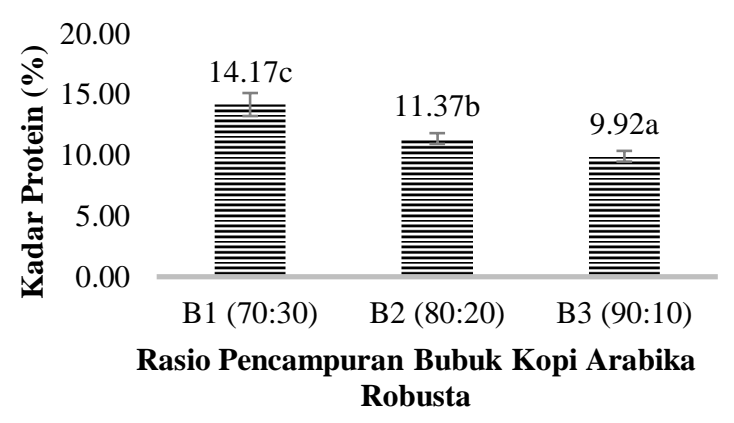

Gambar 2. Pengaruh rasio blending Arabika dan Robusta terhadap kadar protein bubuk kopi espresso (nilai yang diikuti oleh huruf yang sama menunjukkan perbedaan yang tidak nyata), $\mathrm{KK}=8,71 \%$ dan $\mathrm{BNT}_{0,05} 1,30$

Gambar 2 menunjukkan bahwa setiap taraf faktor rasio blending Arabika : Robusta berbeda satu sama lain. Kadar protein terendah terdapat pada formulasi 90:10 (B1) senilai 9,92\% sedangkan protein tertinggi diperoleh pada formulasi 70:30 (B3) senilai 14,17\%. Kadar protein cenderung meningkat jika persentase robusta dalam campuran kopi semakin besar. Hal ini diduga karena kandungan protein pada robusta lebih tinggi sekitar $16,79 \%$ - 18,67\%, dibandingkan arabika yang memiliki kadar protein senilai 8,04\% (Tabel 1). Oleh karena itu, jika jumlah robusta dalam campuran meningkat maka kandungan protein pada bubuk kopi espresso yang dihasilkan juga meningkat.

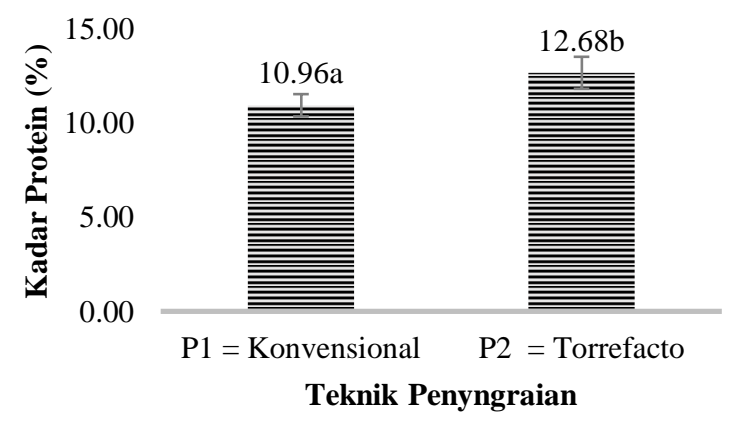

Gambar 3. Pengaruh teknik penyangraian terhadap kadar protein bubuk kopi espresso (nilai yang diikuti oleh huruf yang sama menunjukkan perbedaan yang tidak nyata), $\mathrm{KK}=$ $8,71 \%$ dan $\mathrm{BNT}_{0,05} 1,06$.
Gambar 3 menunjukkan bahwa kadar protein bubuk kopi espresso yang disangrai dengan teknik konvensional berbeda nyata dengan bubuk kopi yang dihasilkan melalui teknik penyangraian torrefacto. Bubuk kopi dari penyangraian torrefacto memiliki kadar protein yang lebih tinggi $(12,68 \%)$ dibandingkan yang disangrai secara konvensional $(10,96 \%)$. Hal ini diduga berhubungan dengan proses reaksi maillard yang berlangsung lebih lama serta adanya penambahan gula pada teknik penyangraian torrefacto.

Proses penyangraian dengan suhu tinggi $\left(190^{\circ} \mathrm{C}\right)$ mengakibatkan denaturasi protein sehingga molekul protein terpecah menjadi lebih sederhana dan dapat dihitung pada prosedur analisa protein kasar kjedahl [12], [20]. Hal ini menyebabkan kandungan protein pada kopi sangrai lebih tinggi dibandingkan kopi beras [9], [21].

Selain itu proses penyangraian baik konvensional dan torrefacto, terjadi reaksi maillard yang berperan penting dalam perubahan warna dan pembentukan citarasa kopi. Reaksi maillard merupakan fenomena karbohidrat bereaksi dengan asam amino menghasilkan senyawa pembentuk citarasa seperti aldehida, keton serta monomer protein lainnya [12], [22]. Kemudian pada torrefacto, pada proses penyangraian ditambahkan gula sehingga reaksi maillard berlangsung lebih intens dibandingkan konvensional sehingga bubuk kopi yang dihasilkan memiliki kadar protein yang lebih tinggi.

\section{Kadar Lemak}

Data hasil analisis kadar lemak pada bubuk kopi yang dihasilkan berkisar antara 5,70\% hingga 8,93\% dengan rata-rata $7,46 \%$. Hasil sidik ragam menunjukkan rasio blending Arabika: Robusta berpengaruh sangat nyata $(\mathrm{P}>0,01)$ dan teknik penyangraian berpengaruh nyata $(\mathrm{P}>0,05)$ terhadap kadar lemak bubuk kopi yang di hasilkan.

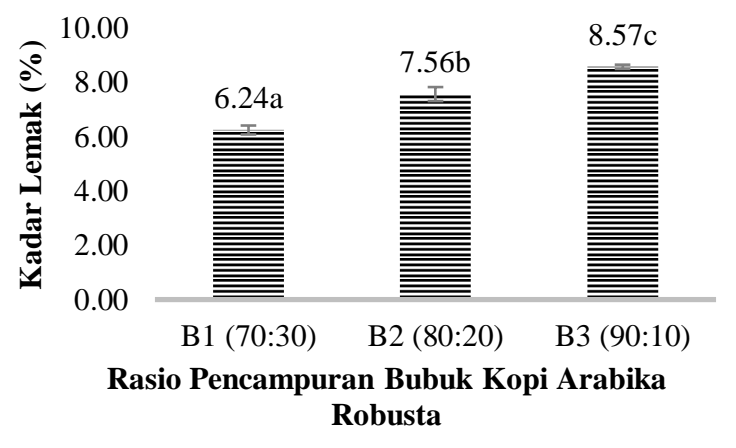

Gambar 4. Pengaruh rasio blending Arabika dan Robusta terhadap kadar lemak bubuk kopi espresso (nilai yang diikuti oleh huruf yang sama menunjukkan perbedaan yang tidak nyata), $\mathrm{KK}=2,11 \%$ dan $\mathrm{BNT}_{0,05} 0,48$ 
Gambar 4 memperlihatkan bubuk kopi espresso dari ketiga taraf perlakuan berbeda nyata satu sama lainnya. Bubuk kopi dari formulasi arabika robusta 70:30 (B1) memiliki kadar lemak terendah sedangkan formulasi 90:10 (B3) mengandung kadar lemak tertinggi. Dari Gambar 4 juga terlihat bahwa semakin besar proporsi arabika dalam formulasi bubuk kopi espresso ini, maka kadar lemaknya cenderung meningkat. Hal ini diduga dipengaruhi oleh kadar lemak arabika yang lebih tinggi $(7,35 \%)$ dibandingkan robusta. Tingginya kandungan lemak pada bubuk kopi akan berpengaruh terhadap pembentukan krema dan body seduhan espresso yang dihasilkan $[6,10]$.

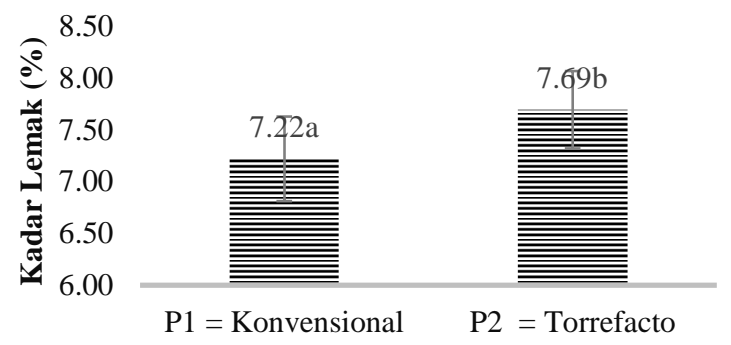

Teknik Penyangraian

Gambar 5. Pengaruh teknik penyangraian terhadap kadar lemak bubuk kopi espresso (nilai yang diikuti oleh huruf yang sama menunjukkan perbedaan yang tidak nyata), $\mathrm{KK}=2,11 \%$ dan $\mathrm{BNT}_{0,05} 0,32$

Gambar 6 menunjukkan pengaruh teknik penyangraian terhadap kadar lemak bubuk kopi espresso yang dihasilkan. Bubuk kopi yang diproses melalui penyangraian torrefacto memiliki kadar lemak yang lebih tinggi $(7,69 \%)$ dan berbeda nyata dengan kadar lemak bubuk kopi yang disangrai secara konvensional $(7,22 \%)$. Pada penelitian ini, penyangraian torrefacto memiliki durasi yang lebih lama (30 menit) dibandingkan penyangraian konvensional (20 menit). Waktu penyangraian yang lebih lama ini diduga mempengaruhi kadar lemak bubuk kopi yang dihasilkan [13]. Pada proses penyangraian, kandungan lipid akan mencair pada kopi beras akan berpindah ke permukaan biji sehingga penampakan biji kopi menjadi mengkilap dan berminyak. Selama proses penyangraian, kandungan air pada biji kopi menguap, sehingga tekstur kopi menjadi berongga dan molekul lipid yang berikatan dengan air menjadi terurai membentuk senyawa lipid yang lebih sederhana [9], [12].

\section{Kadar $\mathrm{Abu}$}

Hasil sidik ragam menunjukkan bahwa kedua faktor penelitian tidak berpengaruh $(\mathrm{P}>0,05)$ terhadap kadar abu bubuk kopi espresso Aceh yang dihasilkan. Rerata kadar abu setiap perlakuan yang diperoleh dari tiga kali ulangan dapat dilihat pada Tabel 2. Dimana jika dibandingkan dengan kadar abu bahan baku pada Tabel
1, kadar abu bubuk kopi espresso Aceh ini cenderung seragam dengan kadar abu bahan baku yang digunakan.

Tabel 2. Kadar abu bubuk kopi espresso Aceh.

\begin{tabular}{clc}
\hline $\begin{array}{c}\text { Rasio Arabika } \\
\text { Robusta }\end{array}$ & $\begin{array}{l}\text { Teknik } \\
\text { Penyangraian }\end{array}$ & Kadar Abu \\
\hline $70: 30(\mathrm{P} 1)$ & & $4,83 \pm 0,29$ \\
$80: 20(\mathrm{P} 2)$ & $\mathrm{B} 1$ (Konvensional) & $4,83 \pm 0,29$ \\
$90: 10(\mathrm{P} 3)$ & & $4,83 \pm 0,76$ \\
\hline $70: 30(\mathrm{P} 1)$ & & $4,50 \pm 0,00$ \\
$80: 20(\mathrm{P} 2)$ & $\mathrm{B} 2($ Torrefacto) & $4,67 \pm 0,58$ \\
$90: 10(\mathrm{P} 3)$ & & $4,67 \pm 0,29$ \\
\hline
\end{tabular}

\section{Kadar Kafein}

Kopi merupakan sumber kafein, yang merupakan alkaloid yang berfungsu sebagai bahan penyegar [8]. Kadar kafein bubuk kopi espresso yang diujikan dipilih berdasarkan nilai proksimat terbaik, dapat dilihat pada Tabel 3.

Tabel 3. Kadar Kafein Bubuk Kopi Espresso

\begin{tabular}{llc}
\hline Sampel & & Kafein (\%) \\
\hline $80: 20(\mathrm{P} 2)$ & Konvensional (B1) & 1,00 \\
& Torrefacto (B2) & 0,97 \\
$70: 30(\mathrm{P} 1)$ & Konvensional (B1) & 1,49 \\
\hline
\end{tabular}

Tabel 2 menunjukkan bahwa kafein bubuk kopi B1P1 lebih tinggi dari pada bubuk kopi B2P2. Hal ini diduga adanya perbedaan kafein bahan baku yang digunakan [9]. Hal ini sesuai dengan pendapat Mulato dan Suharyanto [5] yang menyatakan bahwa kafein pada kopi robusta lebih tinggi dibandingkan pada kopi arabika, dimana robusta mengandung kadar kafein 2,20\%, sedangkan arabika mengandung 1,40\%. Menurut Farah [9], syarat kadar kafein bubuk kopi arabika berkisar antara 0,1-1,2\% dan robusta $0.2-2 \%$. Sedangkan pada penelitaian ini telah sesuai dengan SNI 01-3542-2004 [23], yaitu kadar kafein tidak lebih dari $2 \%$.

\section{KESIMPULAN}

Berdasarkan penjabaran hasil dan pembahasan maka dapat disimpulkan bahwa rasio bubuk kopi arabika dan robusta pada formulasi campuran bubuk kopi espresso Aceh berpengaruh terhadap kadar air, kadar protein dan kadar lemak bubuk kopi yang dihasilkan. Semakin besar rasio Arabika maka kadar air dan kadar lemak bubuk kopi espresso akan meningkat sedangkan kadar protein cenderung turun. Untuk faktor teknik penyangraian berpengaruh terhadap kadar protein dan lemak bubuk kopi espresso yang dihasilkan. Penyangraian dengan penambahan gula atau teknik torrefacto mampu meningkatkan kadar protein dan lemak sebagai hasil dari 
reaksi maillard yang berlangsung lebih lama dibandingkan teknik penyangraian konvensional.

\section{DAFTAR PUSTAKA}

[1] International Coffee Organization. Coffee Production. $\quad$ Internet: https://www.ico.org/prices/po-production.pdf [Nov.10, 2021].

[2] International Coffee Organization. Coffee Exports based on Countries. Internet: https://www.ico.org/prices/m1-exports.pdf [Nov.10, 2021].

[3] International Coffee Organization. Coffee Consumption based on Countries. Internet: https://www.ico.org/prices/m1-exports.pdf

[Nov.10, 2021].

[4] R. Kustiari, "Perkembangan Pasar Kopi Dunia dan Implikasinya bagi Indonesia," Forum Penelit. Agro Ekon., vol. 25, no. 1, p. 43, 2016, doi: 10.21082/fae.v25n1. 2007. 43-55.

[5] Mulato, S dan E. Suharyanto. Kopi Seduhan dan Kesehatan. Pusat Penelitian Kopi dan Kakao Indonesia. Jember .2015.

[6] A. Illy and R. Viani, Espresso coffee: the science of quality. Academic Press, 2005.

[7] Busono. Mengenal Dan Membuat Sendiri Berbagai Menu Kopi Internasional. Koperasi Nukita, Bandung. 2014.

[8] M. Muzaifa and D. Hasni, "Exploration study of Gayo specialty coffee (Coffea Arabica L.): Chemical compounds, sensory profile and physical appearance," Pakistan J. Nutr., vol. 15, no. 5, 2016, doi: 10.3923/pjn.2016.486.491.

[9] A. Farah, Coffee: Production, quality and chemistry. Royal society of chemistry, 2019.

[10] Y. Abubakar, S. Sabariana, R. Rasdiansyah, and D. Hasni, "Sensory characteristic of espresso coffee prepared from Gayo arabica coffee roasted at various times and temperatures," in IOP Conference Series: Earth and Environmental Science, 2021, vol. 667, no. 1, p. 12048.

[11] H. G. Maier, "Changes Produced by Roasting," Espresso Coffee Sci. Qual. Illy A. R. Viani Elsevier Acad. Press. London, UK. Pp, pp. 191-197, 2005

[12] S. Schenker and T. Rothgeb, "The roast-Creating the Beans' signature," in The craft and science of coffee, Elsevier, 2017, pp. 245-271.

[13] F. Wei and M. Tanokura, "Chemical changes in the components of coffee beans during roasting," in Coffee in health and disease prevention, Elsevier, 2015, pp. 83-91.

[14] M. Charles et al., "Understanding flavour perception of espresso coffee by the combination of a dynamic sensory method and in-vivo nosespace analysis," Food Res. Int., vol. 69, pp. 9-20, 2015, doi: 10.1016/j.foodres.2014.11.036.

[15] A. S. Muttalib, W. J. N. Karyadi, and N. Bintoro, "Identifikasi Aroma Campuran (Blending) Kopi Arabika Dan Robusta Dengan Electronic Nose Menggunakan Sistem Pengenalan Pola," Semin Nas Perhimpun Ahli Tek Pertan, pp. 154-163, 2012.

[16] AOAC. Official Methods of Analysis. 16th Edition (Washington D.C.: Association of Analytical Chemist). 2005.

[17] D. Rahmad, D. Hasni, M. Muzaifa, and N. Safraini, "Characteristics of Gayo Coffee's Chemical Compound Based on Different Roasting Condition-An Explorative Study," in Proceedings of ICoChEA (International Conference On Chemistry And Engineering In Agroindustry), 2017, vol. 1, no. 1, pp. 41-44.

[18] Winarno, F.G. Kimia Pangan dan Gizi. M Brio Press, Bogor. 2004.

[19] G. Caprioli, M. Cortese, G. Sagratini, and S. Vittori, "The influence of different types of preparation (espresso and brew) on coffee aroma and main bioactive constituents," Int. J. Food Sci. Nutr., vol. 66, no. 5, pp. 505-513, 2015.

[20] W. B. Sunarharum, D. J. Williams, and H. E. Smyth, "Complexity of coffee flavor: A compositional and sensory perspective," Food Res. Int., vol. 62, pp. 315-325, 2014.

[21] R. Hayati, A. Marliah, and F. Rosita, "Sifat kimia dan evaluasi sensori bubuk kopi arabika," $J$. Floratek, vol. 7, no. 1, pp. 66-75, 2012.

[22] N. Bhumiratana, K. Adhikari, and E. Chambers, "Evolution of sensory aroma attributes from coffee beans to brewed coffee," LWT - Food Sci. Technol., vol. 44, no. 10, pp. 2185-2192, 2011, doi: 10.1016/j.lwt.2011.07.001.

[23] Badan Standarisasi Nasional. SNI 01-3542-1994. Kopi Bubuk. Dewan Stadarisasi Nasional, Jakarta. 1994. 